\title{
Consumer Health Information
}

\author{
Compiled by Susan Murray
}

\section{Canadian Health Network}

The Canadian Health Network http://www.canadian-healthnetwork.ca is an excellent source of health information for personal use and to recommend to your users. However, you may have overlooked a number of its features.

Did you know that articles going back to January 2003 are available? Click on Past Articles at the bottom of the This Month screen to access the partner and magazine features, such as "How Canadians find health information on the Internet" and "Beyond words - the health-literacy connection". You can also sign up to receive Healthlink!, the twice monthly e-mail newsletter featuring all-Canadian articles, events, and little-known health facts.

There are three ways to search the Canadian Health Network: guided search, A-Z search, and keyword search.

For example, to limit by province, do a guided search on a topic such as cancer — note the Narrow Your Search options on the left-hand side. You can narrow your search by topic, group or province. Provinces are listed at the bottom of the screen. You can search on more than one topic, such as cancer and complementary and alternative medicine. You can search on a topic and a province such as cancer and $\mathrm{On}$ tario.

\section{Medical Library Association (MLA)}

MLA struck a Health Information Literacy Task Force in 2003 to help define the librarian's role in working with other professionals to promote health information literacy. Erica Burnham from McGill University and I are on the Task Force. Check the Health Information Literacy Web page http:// www.mlanet.org/resources/healthlit/ for some resources for health and information professionals and health consumers.

MLA News includes a number of items of interest to Consumer Health Information (CHI) librarians.

\section{CHI columns}

A new quarterly consumer health column made its debut in January 2003.

- The "CAPHIS top 100" and the MLA top ten" websites. January 2003, p. 14.

- Consumer health libraries: the next pharmacies? May 2003, pp. 1, 14.

- Tox town: a new approach to environmental health. August 2003, pp. 1, 11.

\section{CHI articles}

"Training for public librarians". March 2003, p. 14. Discusses health sciences librarians conducting training workshops for public librarians.

\section{Internet resources}

There are monthly round-ups of annotated Internet resources.

Those in 2003 have included

- A sa salud: health information in Spanish. January 2003, p. 7.

- Molecular biology. February 2003, pp. 10-11.

- Rehabilitation resources on the web. March 2003, pp. 10-11.

- Psychiatry and clinical psychology. April 2003, p. 10.

- International health. May 2003, p. 8.

- Children's health and family communication. June/July 2003, pp. 9-10.

- Patient safety. August 2003, p. 9.

- Health literacy. September 2003, p. 13.

- Late-life depression resources for patients and their caregivers. October 2003, p. 10.

- Wireless networking. November/December 2003, p. 10.

\section{CHI readings}

The October/December 2003 issue (4/5) of the Journal of Medical Internet Research is a theme issue on consumers searching for health information on the Web (http://www. jmir.org/2003/4/index.htm).

MacDonald, Keith. Online patient-provider communication tools: an overview. Prepared for California Healthcare Foundation. ihealthreports. November 2003 (http://www. chcf.org/topics/view.cfm?itemID=21600).

Credibility, accuracy and readability: consumer expectations regarding online health information. Conducted by manhattanRESEARCH, 2003 (http://www.manhattanresearch.com/ Credibility, \%20Accuracy, \%20and\%20Readability\% 20Executive\%20Summary\%20Findings.pdf).

Eysenbach, Gunther. How do consumers search for and appraise health information on the world wide web? Qualitative study using focus groups, usability tests, and in-depth interviews. BMJ. 2002;324:573-577.

\section{MedlinePlus}

MedlinePlus has added easy-to-read pages in both English and Spanish that bring together the Interactive Health Tuto- 
rials and other easy-to-read materials by topic (http:// www.nlm.nih.gov/medlineplus/easytoread/easytoread_a.html).

\section{Household products database}

The National Library of Medicine (NLM) has developed a consumer's guide that provides easy-to-understand information on the potential health effects of more than 4000 common household products. Some household products contain substances that can pose health risks if they are ingested or inhaled, or if they come into contact with eyes and skin (http://householdproducts.nlm.nih.gov).

\section{Consumer and Patient Health Section of the Medical Library Association (CAPHIS)}

There is a wealth of information on the CAPHIS site (http://caphis.mlanet.org): items for managing a CHI service (planning, collection development, information resources, etc.), a directory of CHI libraries, the CAPHIS Top 100 and MLA Top 10 recommended Web sites, and the newsletter. The current issue (19/4) includes articles on health literacy, a detailed description of NLM's Household Database, and "Health Librarian on the Street - Trends in Consumer Health Libraries".

\section{Collection development}

McNally Bensing, Karen. The "Antiaging" Remedy. Library Journal. 15 January 2004 (http://www.libraryjournal. com/index.asp), select Collection Development.

A Majors Scientific Books Report for Medical Librarians is a useful quarterly publication published by J.A. Majors Company. It includes brief articles, "Alan Rees on Consumer Health" column (the focus of the Fall 2003 issue is complementary and alternative medicine), and regular Brandon/Hill List Updates (https://www.majors.com/libraries/Vol24No4. pdf).

\section{Complementary and alternative medicine}

Health Policy Research Bulletin, November 2003, issue 7, is a special theme issue on complementary and alternative medicine (CAM). It includes an overview article that explains some terminology (such as on complementary and alternative health care therapies (CAHC), integrative health care), the regulation of natural health products (came into effect January 2004), CAHC utilization patterns and trends, safety and effectiveness of CAHC, and an evidence base for evaluating natural health products (http://www.hc-sc.gc.ca/ iacb-dgiac/arad-draa/english/rmdd/bulletin/mainstream.pdf). 